\title{
Statyba
}

\section{COMPLEX EVALUATION OF ECONOMICAL-SOCIAL DEVELOPMENT OF LITHUANIAN REGIONS}

\section{R. Ginevičius \& V. Podviezko}

To cite this article: R. Ginevičius \& V. Podviezko (2001) COMPLEX EVALUATION OF ECONOMICAL-SOCIAL DEVELOPMENT OF LITHUANIAN REGIONS, Statyba, 7:4, 304-309, DOI: 10.1080/13921525.2001.10531740

To link to this article: https://doi.org/10.1080/13921525.2001.10531740

曲 Published online: 30 Jul 2012.

Submit your article to this journal

LII Article views: 200

4 Citing articles: 2 View citing articles 진 


\title{
COMPLEX EVALUATION OF ECONOMICAL-SOCIAL DEVELOPMENT OF LITHUANIAN REGIONS
}

\author{
R. Ginevičius, V. Podviezko \\ Vilnius Gediminas Technical University
}

\section{Introduction}

Centralized planning of economy functioned before the Soviet Union collapse stipulated a relatively balanced development of Lithuanian regions. At that time the state investments into public industrial enterprises were distributed quite evenly in the territory of Lithuania what guaranteed thousands working places in the country regions. Situation changed dramatically after turn into market economy has been made. The state stopped its large-scale investment policy and economical activity naturally began to concentrate in regions, which appear to be better adapted to market conditions. So why now in Lithuania quite significant differences between achieved level of economical-social development of separate regions can be found. For example, per capita GDP of Taurage district comprise only $65 \%$ of Lithuanian average, while in Vilnius district this index exceeds the average by $120 \%$ [1]. Considerable differences in other areas are also found. Districts of Vilnius and Klaipeda (Vilnius and Klaipeda cities particularly) in 1996-98 attracted estimated $2 / 3$ of all foreign direct investments (FDI), which have been made in Lithuania. Including Kaunas district index of FDI of listed regions they would exceed by $80 \%$ [1]. Such concentration of economical activity in several centres of the country stipulated social inequality and therefore has become an issue of state level. Considering this situation from the point of view of economical geography, we should certify a growing difference between two separate economic zones. In one of those zones modern enterprises linked with foreign markets and receiving FDI operate, while in the other, peripheral zone, economical industries creating comparatively insignificant value added prevail, what, in its turn, results in an insufficient level of income of local inhabitants.
Lithuania recently with support of the European Union started activity aimed at smoothing social and economical differences of separate regions. This activity has been financed by national funds and funds granted by European Union's special programmes (such as JSPA, SAPARD structural funds, extended PHARE programme) as well.

National and European Union's support for regions could guarantee the maximal effect only if adequate mechanism of distribution and investing of alloted means was used, the more so, as quite a significant part of national budget means has been provided for construction purposes. Constituent of such a support mechanism is evaluation of level of economical and social development of separate regions. Contemporary methods applied for this purpose involve only limited number of indexes and therefore evaluation of level of development of regions lacks complexity. Authors of the article aim to solve this problem.

\section{Evaluation of regional development in European Union countries}

In European Union countries development of regions has been evaluated by so-called contestability indexes. Recently this phenomenon attracts an increased attention. Contestability could be defined as "ability to produce such goods and services, which correspond to standards of international market, and at the same time to maintain invariably high level of income" [2, 3]. Contestability frequently is considered to be a major indicator of economical policy being implemented. In a study performed according to requisition of European Commission per capita GNP has been treated as the main measure of contestability. This indicator has been split into two components: 
1) GDP per working capita. It roughly corresponds to the productivity of working force in a region (though doesn't account number of working hours);

2) ratio of general number of actually working inhabitants to number of those able to work age inhabitants, ie level of employment.

In the mentioned above study an increase per capita GDP index of a region is considered to be roughly equal to product of two indexes: productivity and increase of level of employment. It has been supposed that differences of per capita GDP in regions (contestability accordingly) and, finally, differences of economical and social development are stipulated by the following factors:

1) structure of economics, characterized by distribution of employees in various spheres of economy. It has been determined that the higher portion of employees works in the spheres of industry and services the greater GDP per capita can be achieved;

2) level of innovative activity estimated in number of patents;

3) infrastructure of region estimated by indexes of transport net;

4) qualifications of work force estimated by number of employees in an appropriate group of educational level.

\section{Complex evaluation of regional development}

Complex evaluation of regional development is urgent because of several reasons. At first, admitting the fact that contestability of regions depends on number and type of enterprises, characteristics of infrastructure, etc, other features of the whole region stipulating social and economical development shall be considered as well. The other features of a region include: physical and social infrastructure of region, level of investments, criminal situation, etc. Secondly, it can appear that one group of indexes are better for one regions, while other indexes give more favourable characteristics of other regions. The third, impact of various indexes on economic and social development of regions can be different.

The considered problem could be solved by formation of a system of partial indexes adequately reflecting level of various aspects of economical and social development of regions and, after that, by esti- mating significance of those partial indexes and integrating them into one generalizing indicator. Determination of such generalized index for each Lithuanian region would let to range them according to the level of economical and social development achieved in each of regions.

Authors of this article based their analysis on partial indexes presented in the publication of Department of Statistics "Lithuanian Districts: Economical and Social Development" [4] (Table 1). In order to compare possible methods of complex evaluation of complicated phenomena, economical and social development of regions have been determined by application of the following methods: evaluation according to the sum of places, geometrical mean, sum of values of indexes [5], and also using graphical-analytical [6] and multi-criteria complex proportional evaluation $[7,8]$.

Evaluation according to the sum of places. It is the simplest method. In this case place of each considered district according to the value of each partial index has to be determined. The sum of places shows the general level of economical-social development of appropriate district in comparison with other districts.

Evaluation according to geometrical mean. An integrated value of $K_{A_{1}}$ (Table 2) based on normalized partial indexes has to be determined as follows:

$$
K_{A_{1}}=\sqrt[n]{\prod_{i=1}^{n} C_{i}} K_{i},
$$

here $K_{i}$ is normalized value of $i$ partial index; $C_{i}$ is significance of $i$ partial index; $n$ is number of partial indexes $(i=1, \bar{n})$.

Evaluation according to a sum of values of partial indexes. An integrated value of $K_{A_{2}}$ based on normalized partial indexes has to be determined as follows:

$$
K_{t_{2}}=\sum_{i=1}^{n} C_{i} K_{i}
$$

Graphical-analvtical evaluation. It provides a visual reflection of economical and social development of regions. For that purpose pie diagrams in which three variables change: partial indexes, corresponding central angles and radius of circle could be used. Normalization of partial indexes of economical and social development has been performed in the following way: 


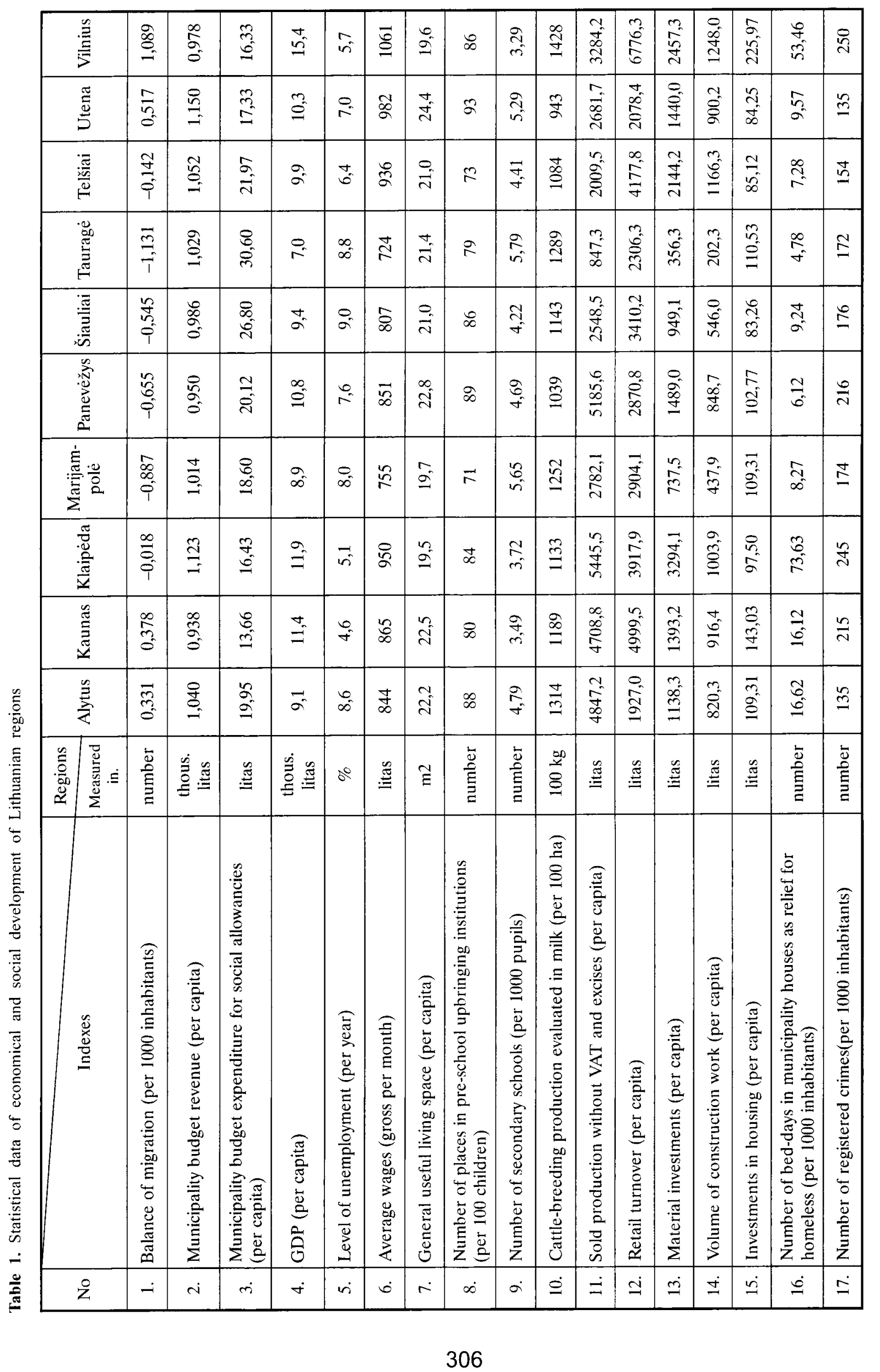


a) when situation improves while value of partial index increases:

$$
K_{+j}^{1}=\frac{K_{i}}{\max K_{i}},
$$

b) when situation gets worse while value of partial index decreases:

$$
K_{-j}^{1}=\frac{\min K_{i}}{K_{i}},
$$

here $K_{i}$ is value of $i$ partial index; $\max K_{i}$ is the greatest value of $n(i=1, \bar{n})$ partial indexes; $\min K_{i}$ is the same, the lowest value.

Indexes with minus sign are also possible. In such case its' recalculated values have been determined:

$$
\begin{gathered}
\widetilde{K}_{i}=K_{i}+\left|\min K_{i}\right|+1, \text { ie } \\
\min K_{i} \Rightarrow \widetilde{x}_{i}=1 \\
\left(K_{i}<0\right) .
\end{gathered}
$$

Integrated index $K_{A_{3}}$ would be equal to:

$$
K_{t_{3}}=\sum_{i=1}^{n} S_{i}=\frac{\pi}{n} \sum_{i=1}^{n} K_{i}^{2},
$$

here $S_{i}$ is area of circle, which radius is equal to $K_{i}$.

Multi-criteria complex proportional evaluation. In this case priorities of economical and social development of the examined regions directly and proportionally depends on values and significances of appropriate partial indexes. Methods of determining priorities has been thoroughly described in books $[6,7]$.

Calculations performed by all five presented above methods of complex evolution have shown the following range of Lithuanian districts corresponding to its economical and social development (Table 2).

Results presented in the table shall play the key role in estimating the efficiency of planning funds (especially of foreign origin) to be implemented into development of regions. In project PHARE 2000 "Social and economical union" 14 million euros have been fixed to be directed into districts of Klaipeda, Taurage, Marijampolè and Utena.

The presented calculations show that districts of Marijampolè and Taurage are really lagging behind. Keeping in mind the results, inclusion of districts of Klaipeda and Utena into the list of the mostly supported ones could be treated as ungrounded, because those districts have achieved a greater level of development comparing with such regions as districts of Šiauliai and Panevėžys. Possibly, the distribution of structural funds of European Union has been made considering only general benefit of a country as a whole.

The analysis also shows that hardly any positive

\begin{tabular}{|c|c|c|c|c|c|c|c|c|c|c|}
\hline \multirow{2}{*}{$\begin{array}{c}\text { Methods of } \\
\text { evaluation of } \\
\text { economical and } \\
\text { social development } \\
\text { of districts }\end{array}$} & \multicolumn{10}{|c|}{ Districts } \\
\hline & Alytus & Kaunas & $\begin{array}{c}\text { Klaipè- } \\
\text { da }\end{array}$ & $\begin{array}{l}\text { Marijam- } \\
\text { polé }\end{array}$ & Panevėžys & Šiauliai & Tauragé & Telšiai & Utena & Vilnius \\
\hline $\begin{array}{l}\text { According to the } \\
\text { sum of places }\end{array}$ & $4-5$ & $4-5$ & 3 & 9 & 7 & 8 & 10 & 6 & 2 & 1 \\
\hline $\begin{array}{l}\text { According to } \\
\text { geometrical mean }\end{array}$ & 4 & 3 & 2 & 9 & 7 & 8 & 10 & 5 & 6 & 1 \\
\hline $\begin{array}{l}\text { According to sum of } \\
\text { values of partial } \\
\text { indexes }\end{array}$ & 4 & 3 & 2 & 9 & 7 & 8 & 10 & 5 & 6 & 1 \\
\hline Graphical-analytical & 5 & 4 & 2 & 10 & 7 & 8 & 9 & 6 & 3 & 1 \\
\hline $\begin{array}{l}\text { Multi-criteria } \\
\text { complex proportional }\end{array}$ & 6 & 3 & 2 & 9 & 5 & 8 & 10 & 4 & 7 & 1 \\
\hline Total & 23,5 & 17,5 & 11,0 & 46,0 & 33,0 & 40,0 & 49,0 & 26,0 & 24,0 & 5,0 \\
\hline Place & 4 & 3 & 2 & 9 & 7 & 8 & 10 & 6 & 5 & 1 \\
\hline
\end{tabular}
relationship could be traced between economical-social development of regions and expenditures of state budget for construction purposes. That once more confirms conclusion about uneven distribution of national budget means.

Table 2. Results of complex evaluation of social and economical development of Lithuanian districts 
On the basis of the presented data (Table 2) comparison of received results with the criterion used by European Commission - GDP per capita - could be done. This comparison has been performed by application of the following formula:

$$
S_{i}=\sum_{i=1}^{n-1} / P_{i_{B V P}}-P_{i j} /,
$$

here $S_{i}$ are results of comparison of development of $i$ region estimated in GDP per capita and estimated by method of complex evaluation;

$P_{i_{B V P}}$ is place of development of $i$ region estimated in GDP per capita $(i=1, \mathrm{n})$;

$P_{i j}$ - place of development of $i$ region estimated by $j$ method of complex evaluation.

The presented comparison shows that application of index used by European Commission (GDP per capita) for evaluating of economical and social development of regions is recommended only for determination of ultimate cases, ie for the mostly developed regions and for mostly lagging behind ones (Table 3 and Fig 1). So this index is applicable for distribution of foreign investments from various appropriate funds. As concerns local investments, including investments in construction, the considered index does not provide enough accurate results, so methods of multi-criteria complex evaluation in this case would be more adequate.

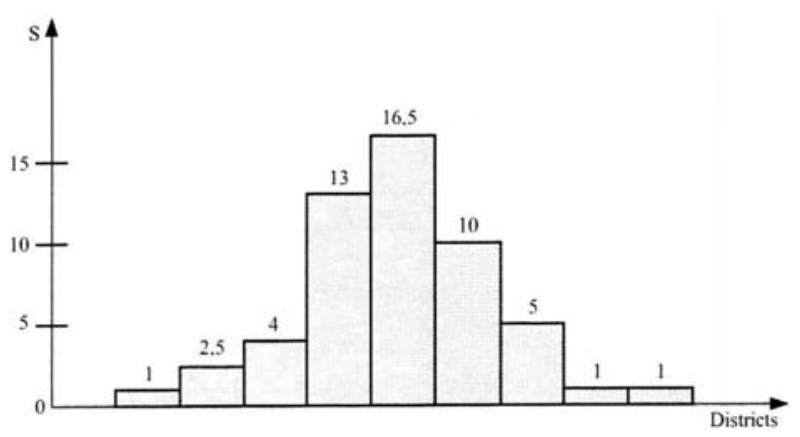

Fig 1. Graphical interpretation of results of comparison of social and economical development of Lithuanian regions estimated by method of complex evaluation and estimated in GDP per capita

\section{Conclusions}

1. The recently used methods of complex evaluation of economical and social development of regions should be accomplished because they do not account all factors stipulating this development and do not provide ways how to integrate them into a complex indicator.

2. Economical and social development of regions can be estimated by the following methods: according to the sum of places, geometrical mean, and also by methods of graphical-analytical and of multi-criteria complex proportional evaluation.

3. Results of complex evaluation of economical and social development of Lithuanian regions have shown that the mostly lagging behind are districts of

Table 3. Results of comparison of social and economical development of Lithuanian regions estimated by method of complex evaluation and estimated in GDP per capita

\begin{tabular}{|c|c|c|c|c|c|c|c|c|c|c|}
\hline \multirow{2}{*}{$\begin{array}{l}\text { Methods of evaluation } \\
\text { of economical and } \\
\text { social development of } \\
\text { districts }\end{array}$} & \multicolumn{10}{|c|}{ Districts } \\
\hline & Vilnius & Klaipèda & Kaunas & Telšiai & Panevéžys & Alytus & Utena & Šiauliai & $\begin{array}{l}\text { Marijam- } \\
\text { polé }\end{array}$ & Tauragè \\
\hline $\begin{array}{l}\text { According to the sum of } \\
\text { places }\end{array}$ & 1 & 2 & 3 & 4 & 5 & 6 & 7 & 8 & 9 & 10 \\
\hline $\begin{array}{l}\text { According to } \\
\text { geometrical mean }\end{array}$ & 1 & 3 & $4-5$ & 6 & 7 & $4-5$ & 2 & 8 & 9 & 10 \\
\hline $\begin{array}{l}\text { According to the sum of } \\
\text { values of partial indexes }\end{array}$ & 1 & 2 & 3 & 5 & 7 & 4 & 6 & 8 & 9 & 10 \\
\hline Graphical-analytical & 1 & 2 & 3 & 5 & 7 & 4 & 6 & 8 & 9 & 10 \\
\hline $\begin{array}{l}\text { Multi-criteria complex } \\
\text { proportional }\end{array}$ & 1 & 2 & 4 & 6 & 7 & 5 & 3 & 8 & 10 & 9 \\
\hline \multirow[t]{2}{*}{ GDP (per capita) } & 1 & 2 & 3 & 6 & 4 & 8 & 5 & 7 & 9 & 10 \\
\hline & 0 & 1 & 2,5 & 4 & 13 & 16,5 & 9 & 5 & 1 & 1 \\
\hline
\end{tabular}


Tauragè, Marijampolè, Šiauliai and Panevėžys, while the mostly developed districts are Vilnius, Klaipèda, Kaunas and Alytus.

4. Distribution of the so-called structural funds of European Union among regions do not completely correspond to the achieved level of their development.

5. Special state budget expenditures did not correspond to the level of economical and social development of Lithuanian regions.

\section{References}

1. Lietuvos Respublikos Ükio ministerija. Verslo plètra: nuomonés, tendencijos, problemos. Vilnius: Metodinis leidybinis centras, 1999, p. 14-28.

2. Kauno technologijos universitetas. Probleminiu regionu kriteriju nustatymas. Kaunas, 1999, p. 7-24.

3. H. Armstrong. Community Regional Policy. London: Printer Publischers, 1997, p. 167-168.

4. Lietuvos apskritys: ekonominè ir socialinè raida / Statistikos departamentas. Vilnius: Statistika, 1999, p. 30-314.

5. В. И. Моисеев, Д. В. Терехин, С. Н. Цыганков / Под ред. В. И. Терехина. Финансовое управление фирмой. Москва: ОАО Экономика, 1998. $350 \mathrm{c}$.

6. R. Ginevičius, V. Podviezko. Statybos imoniu komercinès-ūkinès veiklos efektyvumo kompleksinis ivertinimas // Statyba, VI t., Nr. 4. Vilnius: Technika, 2000 , p. 278 288.

7. E. K. Zavadskas, A. Kaklauskas. Pastatu sistemotechninis ivertinimas. Vilnius: Technika, 1996. 280 p.

8. E. Zavadskas, O. Kaplinski, A. Kaklauskas, J. Brzezinski. Expert systems in construction Industry. Trends, potential \& applications. Vilnius: Technika, 1995. 180 p.

Itteikta 20010503

\section{KOMPLEKSINIS SOCIALINĖS-EKONOMINĖS PLÉTROS IVERTINIMAS LIETUVOS REGIONUOSE}

\section{R. Ginevičius, V. Podviezko}

\section{S a n t r a k a}

Pereinant prie rinkos ekonomikos, išryškẻja didelè diferenciacija tarp atskiru šalies regionų. Tai sukelia didelę socia- linę ittampa, nukenčia investiciju kryptingumas, taip pat investuojant ir $i$ statyba, kuriai reikia nemažos investiciju dalies.

Pagrindas regiono investicijoms - jo socialinè ir ekonominè plètra. Šiuo metu Europos Sajungos Komisijos siūlymu ji ivvertinama, atsižvelgiant i regiono konkurencinguma, kurio konkreti išraiška - bendrasis vidaus produktas, tenkantis vienam regiono gyventojui. Kyla klausimas, ar šis rodiklis pakankamai objektyviai atspindi faktišką regionı̨ socialinę-ekonominę plètrą?

Regiono socialinę-ekonominę plètrą galima apibūdinti ¿̇vairiais aspektais, veiksniais, $\mathfrak{i}$ kuriuos galima žiürèti kaip $\mathfrak{i}$ dalinius kompleksinio dydžio rodiklius. Jų veikimo pobūdis yra nevienodas, kartais netgi prieštaringas, be to, jie išreiškiami pačiais ivvairiausiais mato vienetais. Taigi turime uždavinị, kuri galime spręsti taikydami daugiakriterinius ịvertinimo metodus.

Sprendžiant ši uždavini, dalinių rodikliụ reikšmès imamos iš oficialių šaltinių, o jų reikšmingumai nustatomi taikant ekspertinius ịvertinimus.

Atlikus skaičiavimus ir jų rezultatus palyginus su bendrojo vidaus produkto, tenkančio vienam gyventojui, rodikliu, paaiškéjo, kad remiantis Europos Sajungos Komisijos siūlomu rodikliu nustatomi tik labiausiai išsivystę ir labiausiai atsilikę regionai, todel tai yra pateisinama skirstant Europos Sajungos fondus. Vidaus valstybinems investicijoms paskirstyti tarp regionų tokio vertinimo neužtenka, jis netikslus. Tikslinga taikyti straipsnyje nagrinejamus daugiakriterinius ivertinimo būdus.

Romualdas GINEVIČIUS. Doctor Habil, Professor. Dean of Business Management Faculty. Vilnius Gediminas Technical University (VGTU), Sauletekio al. 11, LT-2040 Vilnius, Lithuania. E-mail: vstud@vv.vtu.lt

Doctor (1975). Doctor Habil (1997, VGTU). Author of 10 books, monographs, about 150 research articles published in Lithuania and abroad. Member of International Academy of Information, Member of Lithuanian Committee for Research Prizes. Research interests: market economy, theory of organisations.

Valentinas PODVIEZKO. Doctor, Associate Professor. Dept of Mathematical Statistics. Vilnius Gediminas Technical University, Sauletekio al. 11, LT-2040 Vilnius, Lithuania. E-mail: 1saulis@rasa.vtu.lt

Doctor (1984). Author and co-author of over 40 publications. Research interests: sampling and forecasting models in economics. 